Archives of Agriculture and Environmental Science

\title{
Assessment of remittance and its impacts on economic growth in Nepal
}

\section{Sushma Banjara*, Seema Karki and Amrit Dumre}

Department of Agricultural Economics and Agribusiness Management, Faculty of Agriculture, Agriculture and Forestry University, Rampur, Chitwan, NEPAL

*Corresponding author's E-mail: sushmabanjara151@gmail.com

\section{ARTICLE HISTORY}

Received: 15 February 2020

Revised received: 10 March 2020

Accepted: 13 March 2020

\section{Keywords}

Financial development

Foreign aid

GDP

Human capital

Productivity

\section{ABSTRACT}

This study delves into the issues related to remittance and its role in the Nepalese economy. Remittance is found to have positive association with human capital formation and financial development while negative impact on productivity and international trade in Nepal. Nepal is one of the leading nations of sending workers abroad received approximately US $\$ 6.29$ billion of remittances, almost 25 per cent of its GDP in 2017/18. The investment of remitted amount in unproductive sectors like consumption expenses rather than in productive sectors has resulted in an increment in overall import. The remitted income has occupied a major position of financing which exceeds all the foreign aid and investment in recent years. Thus, the Government of Nepal should make an appropriate policy to maximize the benefit of remittance and retain the manpower to the sustainable economic growth and development sector of the country.

(C)2020 Agriculture and Environmental Science Academy

Citation of this article: Banjara, S., Karki, S. and Dumre, A. (2020). Assessment of remittance and its impacts on economic growth in Nepal. Archives of Agriculture and Environmental Science, 5(1): 61-66, https://dx.doi.org/10.26832/24566632.2020.050109

\section{INTRODUCTION}

Remittance refers to the money and goods that are transferred by the emigrants to their households, either from urban areas or abroad (Richard and Adams, 2011). Nepal represents the country with a small size economy of US\$25 billion GDP with a share of remittance to its GDP is approximately 25 per cent in 2018 which was only 1.8 per cent in 1995 (MoF, 2018). This indicates that the Nepalese economy is becoming more remittancedependent with the inflows of remittances that have been continually growing over recent decades. The share on the migrant population from Nepal is 3 million; approximately 10 per cent of the total population of the country (Sharma, 2019). The history of labour migration dates back to 300 years ago; in May 1815 agreement between the colonial British government in India and Nepal formally opened up the avenues for Nepalese to be employed overseas with the annual recruitment of Gorkha soldiers from Nepal for the British armed force. Since then, Nepalese have been migrating to North-East India in search of work in the coal mining and agriculture sectors (Kshetry, 2003). This century old tradition undergoes a transformation after the civil war of Maoist party which became one of the push factors for the youths to leave their villages. Especially gulf countries (Saudi Arabia, Qatar, UAE, Oman, and Kuwait), South Korea and Malaysia became the priority destination for them. The new destinations emerged because of the globalizing dynamics and the boom in the oil industry that started in the Middle East in the 1970s (DoFE, 2015). The liberalized economic policy adopted after 1992 helped to formalize labour migrations and opened doors for recruitment and remitting agencies to operate in the country and solicit workers for jobs in the other countries (Shrestha, 2016). Rai and Awale (2016) have reported that about 1500 Nepalese workers on average fly out from Kathmandu international airport to these countries every day. The survey carried out in 2010/11 revealed that approximately 56 per cent of the Nepalese households received remittances, both from internal and external sources.

Different scholars have differently characterized the impact of remittance on economic growth in various countries. Remittance has been considered as a major source of financing in the Nepalese economy but there has been limited study carried out exploring the relationship between remittance and its impact on economic growth in Nepal. Therefore, the objective of the study is to analyze the remittance inflow and its impact in the Nepalese economy. 


\section{METHODOLOGY}

The study is based on the secondary data obtained from the various issues of Economic Survey of Ministry of Finance (Fiscal years 2000/01, 2008/09 and 2018/19), World Bank, Quarterly Economic Bulletin and Economic reports of Nepal Rastra Bank (Central Bank). Different remittance related journal articles, reports and books were also reviewed. Descriptive statistical tools such as bar diagram, tables are used to represent the remittance status in developing countries and South Asia, a pie chart to show the foreign employment status in Nepal and line graph and trend line to discuss the remittance and national economy. Correlation relationship is carried out to show the relationship of remittance income with gross domestic product and gross capital formation and all of this is carried out using MS excel and STATA (version 12).

\section{Empirical findings}

\section{Remittance and economic growth}

Researchers throughout the world have conducted several studies to investigate the impact of remittance on economic growth. There are different conflicting perspectives regarding the impact of remittance on economic growth (Turnell et al., 2008). The optimist argued that the remittances have a positive effect on economic growth as it increases in investment and human capital while pessimists' remittances negatively affect economic growth through inflation and moral hazards resulting from reduced labor supply (De Haas, 2007). Difficulty of disentangling the links between remittance and economic growth might be the cause of this controversy. The study conducted by Tolcha and Rao (2016) in Ethiopia over 1981-2012 found that remittance has a significant impact on economic growth in the short run whereas it has adverse effect in the long run. Cooray (2012) found that remittance has a significant positive effect on economic growth considering education level and financial sector development in South Asia. Similar, a study carried out in Bangladesh over 1975-2013 concluded that the remittance has positive association only in the long run with economic growth (Majumder and Donghui, 2016). Lokshin, Bontch-Osmolovski and Glinskaya (2010) found that the remittance reduces poverty by one fifth between 1995 and 2004 in Nepal. Similarly, Adams (2006) in Ghana and Taylor, Mora, Adams and LopezFeldman (2005) in Mexico also concluded that international remittances reduce poverty. Chami et al. (2005) carried out the study covering 113 countries over 1970 to 1980 showed that the remittances serve negatively and have a significant effect on per capita GDP growth for different groups of the country. A similar study carried out in 100 countries for the period 1975 to 2002 by Giuliano and Ruiz-Arranz (2009) suggested that remittance enhances GDP growth in less developed countries by serving as the alternative to finance development. Richard and Adams (2011) reviewed that international remittances, however, creates a negative impact on labour supply, education, and economic growth, it usually has a positive effect on poverty and health in the developing countries. Fajnzylber and Lopez (2007) concluded the positive but relatively small impact of remittance on growth and investment. The study on the impact of remittances on economic growth in Nepal showed that remittance has positive relationships with financial development and human capital accumulation while a negative association with productivity and international trade signifies the mixed impact of remittance flows on the economic growth (Dahal, 2014). Likewise, remittance has contributed to create human capital through investment in education and health and lift up people from the extreme poverty group in Nepal (Sharma, 2019). Remittance may deteriorate economic growth as it led to moral hazard and the Dutch disease (real appreciation and loss of competitiveness in tradable goods) by hollowing out of adult members and creating inefficiency in farm production due to shortage of labor and income substitution effect (Sharma, 2019; Richard and Adams, 2011).

The remittance and economy of developing nations and south Asia

More than 247 million people or 3.4 percent of the world population, live outside their countries of birth. United States, followed by Saudi Arabia, Germany, the Russian Federation, the United Arab Emirates, the United Kingdom, France, Canada, Spain, and Australia are the top migrant destination country in the world (World Bank, 2016). Countries having higher income are the largest sender of the remittance where the United States (US\$68 billion) followed by the United Arab Emirates (US\$44 billion) and Saudi Arabia (US\$36 billion) (World Bank, 2019). In 2018, the top recipient countries recorded were India, China, Mexico, the Philippines and the Arab Republic of Egypt. As a share of GDP, however, smaller countries such as Tonga (35.2 per cent), the Kyrgyz Republic (33.6 per cent), Tajikistan (31 per cent), Haiti (30.7 per cent), Nepal (28 per cent), and El Salvador (21.1 per cent), were the largest recipients in 2018 (Figure 1).

\section{South Asia}

Remittances to South Asia upsurge by an estimated 12.3 per cent in 2018, faster than the 5.7 per cent observed in 2017. In India growth of remittance is 14 per cent which remained moderate (6.7 percent) in Pakistan whereas Bangladesh, remittances showed a brisk uptick of 14.8 per cent and Sri Lanka witnessed remittance growth of 3.8 percent in 2018 (World Bank, 2019). India is the highest remittance (US $\$ 78.6$ billion) recipient country in South Asia followed by Pakistan (US\$21 billion) and Bangladesh (US $\$ 15.5$ billion). In terms of gross domestic product (GDP) Nepal secured the highest position among all in 2018, having 28 per cent. This implies that the Nepalese economy is highly dependent on the remittance (Table 1 ).

\section{Foreign employment in Nepal}

According to the population of Nepal, about 500 thousand people entered the labour market every year creates a big challenge to provide employment opportunities. The nation is unable to extend the employment market as expected. Labor force survey 2017, showed that unemployment rate in Nepal is 11.4 per cent. 
US\$ billion, 2018

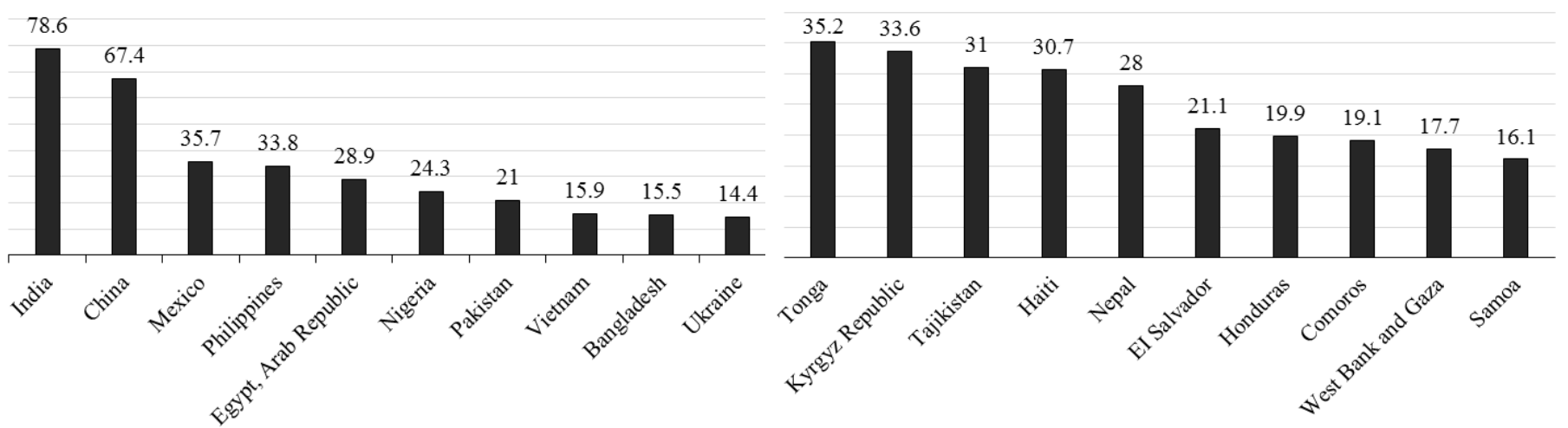

Figure 1. Top remittance receiving countries in 2018 (Sources: World Bank staff estimates, World Development Indicators, IMF Balance of Payments Statistics; Note: GDP = gross domestic product).

Table 1. Remittance inflows to top five South Asian countries in 2018

\begin{tabular}{lccc}
\hline & \multicolumn{3}{c}{ Year: 2018} \\
\hline Country & \% of GDP & Country & Amount (US\$ billion) \\
Nepal & 28.0 & India & 78.6 \\
Sri Lanka & 8.1 & Pakistan & 21.0 \\
Pakistan & 6.8 & Bangladesh & 15.5 \\
Bangladesh & 5.4 & Nepal & 8.1 \\
India & 2.9 & Sri Lanka & 7.5 \\
\hline
\end{tabular}

Sources: World Bank staff estimates, World Development Indicators, and International Monetary Fund (IMF) Balance of Payments Statistics.

The increase in the unemployment rate in the country compel millions of youth to fly overseas for foreign employment. About 4.30 million youths have gone abroad in foreign employment through formal and informal way. However, more than 167 countries have been opened for foreign employment by personal initiatives; only 110 countries have been institutionally opened for foreign employment (MoF, 2018).

Of the total 4,365415 licensed migrant workers, 4167310 were male and 198105 were female till FY 2017/18. Malaysia is the first destination providing foreign employment to 1313658 (30.1 per cent) of Nepalese workers followed by Qatar 1196168 (27.4 per cent), Saudi Arab 880951 (20.2 per cent), UAE 572470 (13.1 per cent) and 402468 (9.2 per cent) in other countries (Figure 2). In Nepal, lack of employment opportunities, political instability, the low salary structure, government liberal policy within the nation and higher demand for the labour in the industrialized Asian and middle-east countries are major causal factors of foreign employment. Similarly, the majority of Nepalese students who have gone abroad (United States, United Kingdom, and Australia, etc.) for higher studies have decided not to return to because of a lack of opportunities in the nation (Dhungana, 2012).

\section{The remittance and Nepalese economy}

The increasing number of emigrants every year for employment raises the amount of remittance substantially. Remittances have become one of the major factors to contribute to household income and GDP of the nation (DoFE, 2014). As shown in Figure 3 , the remittance income in Nepal was about NRs.10 billion in 1998 was drastically increased from NRs.65 billion in 2004 to NRs.209 billion in 2008. In FY 2017/18, the remittance income in Nepal is approximately NRs.755 billion (MoF, 2018). The trend of remittance income of Nepal has depicted through the figure below revealed that the share of the remittance to GDP has been dramatically increased over the recent decades. Similarly, the relation between remittance income and GDP is found to be highly correlated (0.9914) at 0.01 level of significance with about NRs.1074 billion of average GDP.

The contribution of the remittance on the national economy can be computed with remittance to GDP ratio which is shown in the figure below. Even in the presence of the wide trade deficit and rising burden of debt servicing, the surplus in current account and balance of payment is due to elevated levels of remittance inflows in recent years (Shrestha, 2008). Chami, Hakura and Montiel (2009) also discussed that growth volatility could be stabilized through remittance flows as raise in migrant's remittance to GDP ratio by one per cent reduces the standard deviation of GDP growth by 0.16 . The remittance to GDP ratio is relatively higher compared to other South Asian countries. The annual remittance contribution to GDP has been increasing since FY 2000/01 and decrease in FY 2009/10 and again raised to 29 per cent in FY 2014/15 which is 24.9 per cent in FY 2017/18 (Figure 4).

The remittance income and gross capital formation has been depicted through the Figure 5. Sapkota (2013) discussed that only 2.4 per cent of remittance is used in capital formation and rest are spent on day to day expenditure of households in Nepal. Similarly, (Dhungana, 2012) evoked about the dearth of the resource for investment due to consumption-oriented pattern of remittance utilization in Nepal. The average gross capital formation is found to be NRs. 405 billion. The relation between remittance income and gross capital formation is found to be highly correlated (0.9766). Similarly, the relation between GDP and gross capital formation is also highly significant and positive. 
Foreign Employment by Countrywise till 2017/18

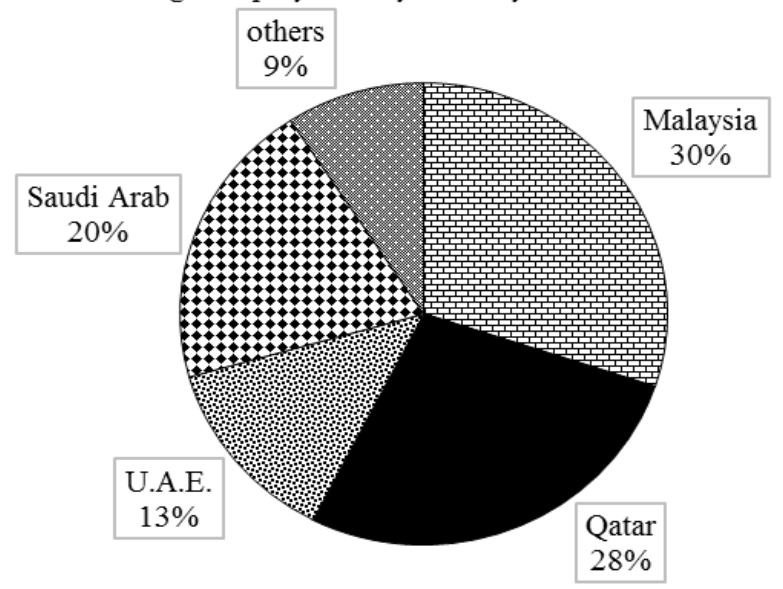

Figure 2. Country wise foreign employment in Nepal (Source: Ministry of Labor, Employment and Social Security and Department of Foreign Employment).

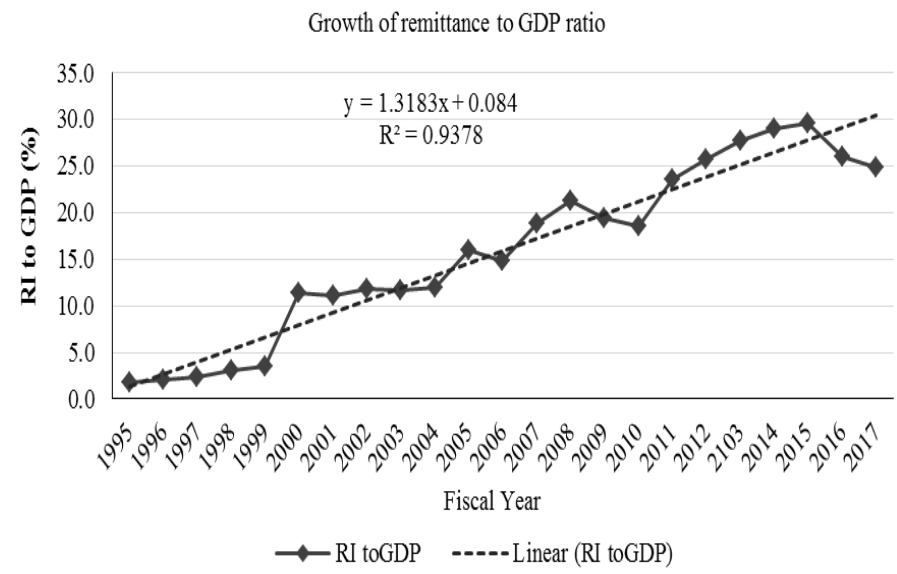

Figure 4. Growth of remittance to GDP ratio over FY 1994/95-2017/18 (Source: Economic Survey, 2018/19).

Remittance has become a major source of foreign currency reserves which have now sufficient for mechanizing and service imports of more than a year. It has increased the liquidity in the banking system and the lack of other investment opportunities in the nation leads the investment into the unproductive sectors (consumption growth) that results in increment in overall import in recent years (Dhungana, 2012). Similarly, the study carried out by Dhungel (2014) also disclosed that the remittance contributes just 0.07 percent in gross domestic product implies that international remittance is spend mostly on consumption expenditures rather than investing on the productive sector. Damber (2017) suggested that a substantial increase in remittance results in lower domestic production due to the emigration of youths and dependency on imports rather than investment has deteriorate GDP per capita of Nepal. Sharma (2019) revealed that remittance results in an increase in import of luxurious goods as well as eroded the competitive advantage of the country by debilitating the export sector which leads to the trade deficit. The import of goods has been inclined from about NRs. 284 billion to NRs. 1242 billion over FY 2008/09 and FY 2017/18 respectively. The rapidly increasing imports are highly financed by remittance, while the export worth about NRs. 67 billion during FY 2008/09 was approximately NRs.81 billion

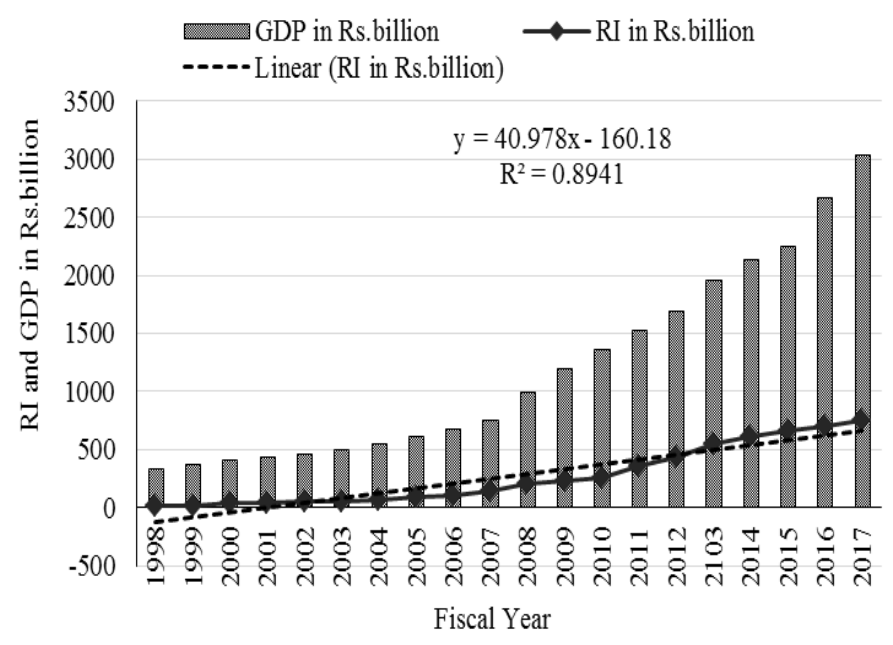

Figure 3. The remittance income and gross domestic product (GDP) over FY 1997/98-2017/18 (Source: Economic Survey, 2018/19).

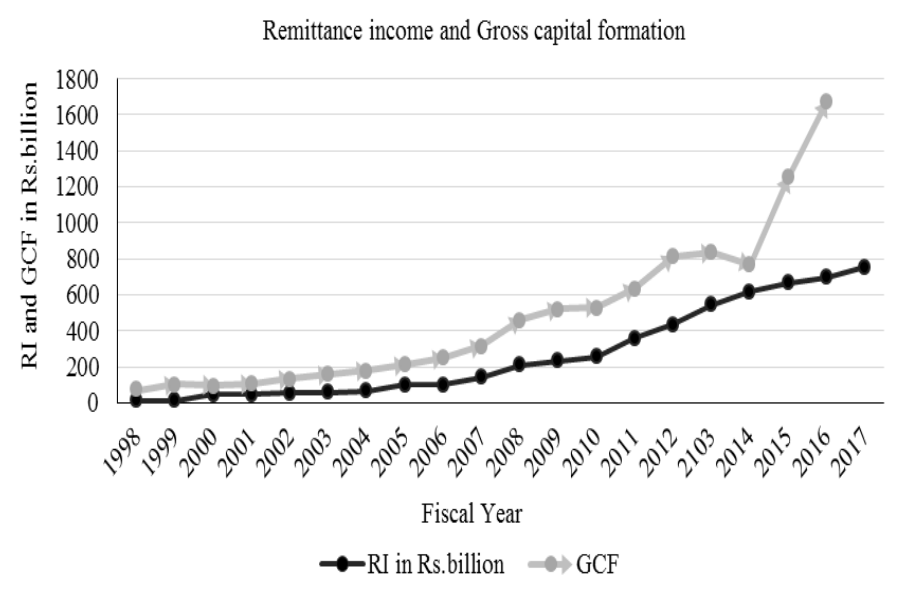

Figure 5. Remittance income and Gross Capital Formation over FY 1197/98 -2017/18 (Source: Economic Survey, 2018/19).

only at FY 2017/18 represents the trade deficit scenario of the nation (Figure 6).

The foreign aid is received in the form of grants and loans from bilateral and multilateral sources. As per the Ahamada and Coulibaly (2013) and Giuliano and Arranz (2005) remittance represents the major part of external finance exceeding export revenues, foreign direct investment (FDI) and aid for most of the developing countries. In the case of Nepal, the flow of foreign aid which has been remained nearby the remittance income during FY 2001/02 has consistently become lower than remittance income. Remittance has drastically increased from FY 2005/06, an occupied position as a major source of financing to the foreign aid in FY 2017/18 as shown in Figure 7.

\section{Policy and legal frameworks}

The liberalized economic policy adopted after 1992 helped to formalize labour migrations and opened doors for recruitment and remitting agencies to operate in the country and solicit workers for jobs in the other countries (Shrestha, 2016). In past, the government of Nepal responded with the promulgation of Foreign Employment Act, 1985 to regulate foreign employment but failure of this act gives rise to new Foreign Employment Act 2007 for dignified, organized and reliable foreign employment. 


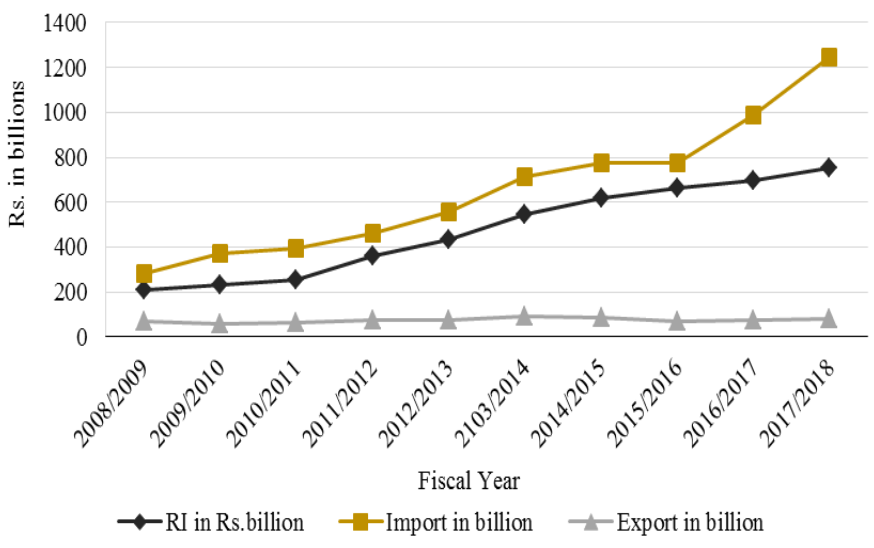

Figure 6. Remittance income and total imports and exports of the goods over FY 2008/09-FY 2017/18 (Source: Economic Survey, 2018/19).

The government introduced National Labour Policy 1999 and Foreign Employment Policy 2012 to provide a safety and accessible migration process and to protect the rights of Nepali workers involving in foreign employment. Foreign Employment Act (2007) has removed all gender-based discriminatory clauses and made provision that only license holder manpower agencies can deal with foreign employment (Shrestha, 2008). The ThreeYear Interim Plan had adopted the policies and strategies for providing pre-departure training, life and accidental insurance for the contract period, the establishment of labor commission and labor tribunal. Recently, the Constitution of Nepal has secured the right to employment and right to labor as basic rights. The Act on Right to Employment-2018 obliged all local levels to have Employment Service Center (ESC) to list out unemployed people, to provide at least 100 days of employment during a fiscal year under the Prime Minister Employment Programme. The government of Nepal has brought 'National Employment Policy 2016' and Foreign Employment Policy 2012 into implementation as per the commitment for sustainable development goals to ensure safe and secure employment through International Labour Organization (ILO) Convention. The Fifteenth Plan also aims to make foreign employment safe and secure, dignified and organized. Similarly, more than 167 countries have been opened for foreign employment by personal initiatives but only 110 countries have been institutionally opened for foreign employment by the government of Nepal (MoF, 2018).

The role of remittance for a nation is very significant because the investment of government is very low in this sector; the remittance inflow rescued the economy during ten years of insurgency period and the worldwide financial crisis during 2007 or 2009. On this dilemma of remittance inflow of Nepal, the government should make proper policy to maximize the benefit of remittance and retain the manpower to the sustainable economic growth and development sector. Similarly, to minimize the sapping effects of the remittance at the societal level, policymakers could come up with the idea of capacity building activities (Sharma, 2019). Government could formulate policies like sending the remittance only through official channel,

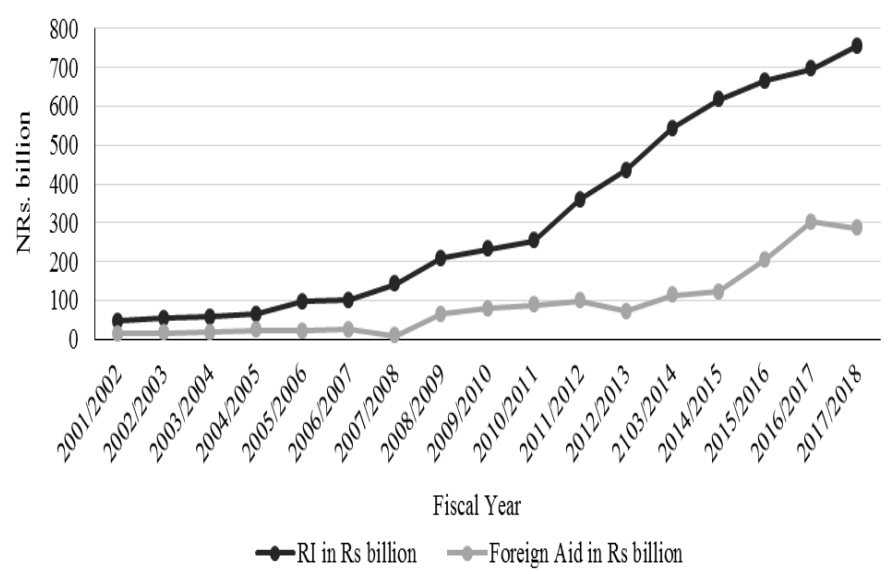

Figure 7. Status Remittance income and foreign aid in Nepal over FY 2001/02-2017/18 (Source: Economic survey, 2018/19).

encouraging migrants to keep their savings in financial assets in the country rather than holding in abroad to increase the levels of remittance and creating environment for migrants to invest in productive assets within the country (Pant, 2011).

Open Access: This is an open access article distributed under the terms of the Creative Commons Attribution 4.0 License, which permits unrestricted use, distribution, and reproduction in any medium, provided the original author(s) if the sources are credited.

\section{Conclusion}

This study attempted to analyze the relationship between remittance and economic growth in Nepal through the study of different empirical articles. It concludes that many economists are optimistic that the remittance can be a major contributor to economic growth while some of them found remittance to have a negative impact on it. This review shows that more work is needed to be carried out with appropriate methodology to resolve the controversy regarding the impact of remittance on economic growth and other areas. Nepal is one of the leading nations of sending workers abroad, it ranks the fifth largest recipient of remittance in term of GDP in the world and first among South Asian countries in the year 2018. Various study showed that remittance has a positive association with financial development and human capital formation while the negative impact on productivity and international trade in Nepal. The remittance being invested in the unproductive sector leads to an increase in the overall import of goods which creates dependency and slows down the economic growth in the long run. Remittance has been an important avenue for assisting family members to lift their livelihoods but couldn't be the best way for development without its investment in productive sectors. Therefore, the government should make appropriate policies to maximize the profit of remittance and retain the manpower to the sustainable economic growth and development sector of the country. 


\section{REFERENCES}

Adams, J. (2006). Remittances and poverty in Ghana. Washington, DC: World Bank.

Ahamada, I. and Coulibaly, D. (2013). Remittances and growth in sub-Saharan African countries: Evidence from a panel causality test. Journal of International Development, 25: 310-324.

Chami, R., Fullenkamp, C. and Jahjah, S. (2005). Are immigrant remittance flows a source of capital for development. IMF staff Paper 52. Washington, DC: International Monetary Fund.

Chami, R., Hakura, D. and Montiel, P. (2009). Remittances: An automatic output stabilizer. Washington, DC: International Monetary Fund.

Cooray, A. (2012). The Impact of Migrant Remittances on Economic Growth: Evidence from South Asia. Review of International Economics, 20(5): 985-998.

Dahal, P. (2014). The impact of remittances on economic growth in Nepal: an analysis of a significant basis of development. Asia Pacific Journal of Public Administration, 2610-282.

Damber, U. (2017). The Impact of Remittances on Economic Growth in Nepal. Journal of Development Innovations, 114-134.

De Haas, H. (2007). Remittances, migration and social development: a conceptual review of the literature. United Nations Research Institute for Social Development, Geneva. Retrieved from http://essays.ssrc.org/ remittances_anthology/wp-content/uploads/2009/07/Topic_1_deHaas.pdf

Dhungana, B.R. (2012). Remittance and Nepalese Economy. Retrieved from https://www.researchgate.net/publication/244810914

Dhungel, K.R. (2014). Does Remittance in Nepal Cause Gross Domestic Product? An Empirical Evidence Using Vector Error Correction Model. International Journal of Econometrics and Financial Management, 2(5): 168-174.

DoFE. (2014). Labour Migration for Employment A Status Report for Nepal: 2013/2014. Government of Nepal, Ministry of Labour and Employment.

DoFE. (2015). Details about foreign employment permit issued. Kathmandu: Department of Foreign Employment.

Fajnzylber, P. and Lopez, H. (2007). Close to home: The development impact of remittances in Latin America. Washington, DC: World Bank.

Giuliano, P. and Arranz, M.R. (2005). Remittances, Financial Development, and
Growth. IMF Working Paper. International Monetary Fund.

Giuliano, P. and Ruiz-Arranz, M. (2009). Remittances, financial development and growth. Journal of Development Economics, 90: 144-152.

Kshetry, D. (2003). Remittances: Costs and Benefits. Nepal Rastra Bank Samachar, 9-12.

Lokshin, M., Bontch-Osmolovski,, M. and Glinskaya, E. (2010). Work-related migration and poverty reduction in Nepal. Review of Development Economics, 14(2): 323-332.

Majumder, S. C. and Donghui, Z. (2016). Relationship between Remittance and Economic Growth in Bangladesh:an Autoregressive Distributed Lag Model (ARDL). European Researcher, 104(3): 156-167.

MoF. (2018). Economic Survey 2018/19. Kathmandu, Nepal: Government of Nepal.

Pant, B. (2011). Harnessing Remittances for Productive Use in Nepal. 23(1).

Rai, A. and Awale, S. (2016). Killed in the line of duty. Retrieved from https://nepalitimes.atavist.com/nepalis-killed-in-theline-of-duty.

Richard, H. and Adams, J. (2011). Evaluating the Economic Impact of International Remittances On Developing Countries Using Household Surveys: A Literature Review. Journal of Development Studies, 47(6): 809-828.

Sapkota, C. (2013). Remittances in Nepal: Boon or Bane? The Journal of Development Studies.

Sharma, B. (2019). Remittances and Capacity Building Issues in Nepal. https://doi.org/10.1007/978-3-030-16740-0_9

Shrestha, P. (2008). Contribution of Foreign Employment and Remittances to Nepalese Economy. 20.

Shrestha, P.K. (2016). Liberalization and Growing Dependency of Nepalese Economy. Kathmandu, Nepal: Nepal Rastra Bank.

Taylor, J., Mora, J., Adams, J. and Lopez-Feldman, A. (2005). Remittances, inequality and poverty:evidence from rural Mexico. Department of Agricultural Economics, University of California, Davis, CA.

Tolcha, T.D. and Rao, D.N. (2016). The impact of economic growth in Ethiopia. Indian Journal of Commerce \& Management Studies, VII(2).

Turnell, S., Vicary, A. and Bradford, W. (2008). Migrant-worker remittances and Burma: an economic analysis of survey results.

World Bank. (2016). Migration and Remittance Book 2016. NW, Washington, DC. World Bank. (2019). Migration and Remittances Recent Developments and outlook. 